International Journal of Linguistics, Literature and Translation (IJLLT)

ISSN: 2617-0299 (Online); ISSN: 2708-0099 (Print)

DOI: $10.32996 / \mathrm{jjllt}$

Journal Homepage: www.al-kindipublisher.com/index.php/ijllt

IJLLT

\title{
An Investigation of Factors Causing English Mispronunciation of Students in English for International Communication
}

\author{
Sawitri Suwanaroa ${ }^{1}$, Sutarat Polerk ${ }^{2} \&$ Rommel V. Tabula*3 \\ ${ }^{1}$ Faculty of Business Administration and Liberal Arts, Rajamangala University of Technology Lanna Tak, Thailand \\ ${ }^{2}$ Faculty of Business Administration and Liberal Arts, Rajamangala University of Technology Lanna Tak, Thailand \\ ${ }^{3}$ Faculty of Business Administration and Liberal Arts, Rajamangala University of Technology Lanna Tak, Thailand \\ Corresponding Author: Rommel V. Tabula, E-mail: ajarnrommel@gmail.com
}

\section{ARTICLE INFORMATION \\ Received: October 10, 2020 \\ Accepted: November 22, 2020 \\ Volume: 3 \\ Issue: 11 \\ DOI: 10.32996/ijllt.2020.3.11.19}

\section{KEYWORDS}

English pronunciation, factors affecting mispronunciation, Thai undergraduate students

\section{ABSTRACT}

English has been recognized as a lingua franca in different aspects of communication such as international business, academic context, science and technology. Despite the constant efforts of developing English education in Thailand, studies have shown that the achievement of Thai students was still unsatisfactory. Additionally, previous studies revealed Thai EFL learners faced a number of difficulties in pronunciation and speaking. The purposes of this study were to investigate the levels of the factors and the most and least factors causing in English mispronunciation of 2nd and 3rd year students in EIC at RMUTL Tak campus. Fifty-one students were purposively selected from EIC of 2nd and 3rd year in 2019. The research instrument included questionnaire and adopted Likert scale for data analysis. The results found that 2 nd and 3 rd year students in English for International Communication (EIC) Program evaluated the factor causing in English mispronunciation found that 1 ) the first language interference factor have the highest mean value 2) phonetic ability factor 3) experience in studying English factor and 4) motivation factor have the lowest mean value.

\section{Introduction}

English is the common language used to communicate around the world. Nowadays, people have more opportunity to learning English and to have more chance to looking job in future. Correct English pronunciation in different situations will enable you to improve your English skills in all aspects. Whether social, cultural, technological and environmental is an incentive that creates a well-integrated learning, practice speaking and using more English to learn from their own mistakes. It is an opportunity to improve your English speaking skills which will be useful in future work. It is also a part that encourages those involved to realize the benefits and use of correct English sentences.

Haymes (2000) commented that pronunciation is important for speaking and listening in communication for the importance to speak. The speaker needs to pronounce clearly and correctly. For listening, the listener must be able to analyze the words that are heard according to the sound system in the audio system in order to correctly interpret the meaning. Therefore, consonant and vowel sounds in English are important elements in language learning, problems and obstacles. There are many ways to study English in Thailand. Correct pronunciation according to native speakers is a major problem. Some English voices are still a pronunciation problem for Thai people.

Therefore, the researchers interested to studying the English pronunciation characteristics. That is for the English language of the 2nd and 3rd year students English for International Communication program. Gillette (1994) proposed that the pronunciation inaccurate English and can cause misunderstandings, prejudices or serious consequences. Goodwin (2001) said that the teaching of English vocabulary and sentence structure, but that is not enough. If the learner is unable to voice the native speaker, then can understand in addition speaking English with a Thai accent makes communication not as effective. It should be because the correct pronunciation cannot be understood by the native speaker. It is very important to understand

K
C
Published by Al-KindiCenter for Research and Development. Copyright (c) the author(s). This is an open access article under CC BY license (https://creativecommons.org/licenses/by/4.0/) 
the English pronunciation because many of the English words similar as well as. Ever native speakers are still wrong the pronunciation at the same time. Also, this topic will be very useful for the students and who are learning the English language.

\section{Objectives of the study}

1. The levels of the factors causing in English mispronunciation of 2 nd and 3rd year students in EIC at RMUTL Tak.

2. The most and least of factors causing in English mispronunciation of 2nd and 3rd year students in EIC at RMUTL Tak.

\section{Literature Review}

\subsection{English Pronunciation}

All around the world, there are a lot of people with strong desire to learn and speak English with correct pronunciation. Pronunciation is learnt by repeating sounds and correcting them when produced inaccurately. When learners start learning pronunciation they make new habits and overcome the difficulties resulting from the first language. And according to Yates (2002 as cited in Pourhosein Gilakjani, 2016), pronunciation is the production of sounds that is used for making meaning. Avery \& Ehrlich (1987) pointed out that the sound system of the native language can influence the student's pronunciation of English in different ways, mainly when a learner encounters sounds in English that are not part of the sound system of the learner's native language.

We should know that native-like pronunciation may be an ideal goal only for some learners and not for all. Intelligibility is a logical aim for the majority of learners. They like to retain their foreign accent because it is a part of their identity. Native-like pronunciation may be an inappropriate goal for most learners. Understandable pronunciation should be one of the basic aims of language learners. Pronunciation instruction has some realistic aims that need to be emphasized in order to develop communicative competence.

\subsection{Factors Affecting Pronunciation Learning}

The researcher mentions some of the important factors that affect the learning of pronunciation. In the past, several researchers have gone to great lengths to suggest the many factors which affect students' pronunciation (e.g., Brown, 1994; Celce-Murcia et al., 1991; Gillette, 1994; Kenworthy, 1987). In this regard, previous studies have repeatedly shown that factors such as native language, age, exposure, innate phonetic ability, identity and language ego, and motivation and concern for good pronunciation ability appear to have an influence on the teaching and learning of pronunciation.

\subsubsection{Native Language}

This definition of native speaker with a mother tongue speaker. A native language is generally the first one a child is exposed to. Also stated that the native language is the most influential factor in accounting for students' English pronunciation, especially foreign accents. Some early studies referred to the process of learning one's first or native language as first language. According to Avery and Ehrlich (1987), learners who speak different languages speak a target language in different ways. The way they speak the target language is sometimes slightly different and sometimes highly different from that of native speakers. If the students are familiar with the sound system of their native language, they will be able to effectively diagnose their own difficulties. In this sense, as asserted by Senel (2006), it should be noteworthy that interference or negative transfer from the first language is likely to cause errors in aspiration, intonation, rhythm, and melody in the target language. For example, these problems can occur when the rules for combining the sounds in syllable forms are different in two languages.

\subsubsection{Prior English Pronunciation}

The lack of opportunity to practice English pronunciation is another prominent problem in the improvement of English pronunciation. Several studies compared the accuracy of pronunciation of people living in English-speaking countries and those who did not. They revealed that learners who did not live in an English speaking country faced problems in mastering English pronunciation. For instance, Siriwisut (1994) and Serttikul (2005) indicated that language experience has an effect on pronunciation ability. In their studies, language experience means the opportunities to use the English language in daily lives.

These studies suggested that students with poor pronunciation, who are regarded as less experienced, had more language transfer problems than those with good pronunciation. For this reason, the students with good pronunciation would improve more easily than those with poor pronunciation. Senel (2006) pointed out that learners living in an English-speaking country or community where English is the second language have many more opportunities to listen to and to use the target language. In addition, success in learning and teaching English depends on both students' ability and their exposure to the target language. Teaching a conversation or a dialogue is, therefore, not enough to help students improve their speaking 
skills. Likewise, Brown (1992) stated that students can pronounce well if they spend time on pronunciation with full attention and interest. In short, students could simply improve the development of their pronunciation by themselves.

\subsubsection{Phonetic ability}

There is a common view that some people have a better ear capacity for foreign language than some other people. So, they are able to discriminate between the two sounds more accurately than the others and able to imitate sounds better. We can accept these people as those with phonetic abilities.

Also, this phonetic ability of the learner affects the development of his/her pronunciation. But it does not mean that people who have a better phonetic ability will be successful but the others won't be successful.

The phonetic ability was sometimes called phonetic coding ability. It is a common view that some people have better listening skills for a foreign language. For example, they are able to discriminate between two sounds more accurately than others and also to imitate sounds better. There are several devices to motivate the poor pronunciation of the learners such as the phonetic labs and remedial pronunciation teaching techniques. Kanoksilapatham (1992) suggested that some elements of learning are a matter of awareness of the different sounds. Additionally, learners' pronunciation ability can be improved by making a greater effort and concentrating on particular sounds.

\subsubsection{Motivation}

If the learners are highly motivated to have a better pronunciation, they can develop a concern for pronunciation, and become more eager activities to speak English language within pay more attention for the sounds of language, and they try to produce better of pronunciation. Motivation can be the key to learn the target language, and they try to produce better sounds. Here it must be pointed out what the motivation is and how the learners will be motivated. According to Brown (1994:114- 115) the motivation is thought of as an inner drive, impulse, emotion, or desire that moves one to a particular action. He also stated that learning a foreign language requires some of all three levels of motivation which can be global, situational, or task-oriented. For example, a learner may possess high global motivation but low task motivation on the written mode of the language.

On the one hand, some factors such as intelligence, and self-confidence have much contribution to the formation of motivation. For example, to motivate the less intelligent people will be more difficult than the intelligent ones because the people cannot appeal to their needs. Motivation, of course, is a number of different kinds of attitudes and can be divided into two basic types: instrumental and integrative motivation. The teachers may need to discern the source of a student motivation in order to meet particular needs. That is, pronunciation teaching must be directed according to the needs, attitudes, intelligence, etc. of the learners. And therefore teachers will spend less time for motivating. If the learners are highly motivated to have a better pronunciation, they can develop a concern for pronunciation. At the same time, motivation can be achieved by paying attention to the learners' concern for pronunciation because learners generally are not aware of that the way they speech is full misunderstanding for the hearer. Consequently, some factors that are effective in pronunciation.

All of these factors much influence on the learners. We cannot change and affect some of these factors, for example, it is impossible for us to change the phonetic ability. It is clear that the influence of age is undeniable in language learning process. When we take into consideration the children of immigrants, we see the difference between the pronunciations.

Since they start their learning process in their early ages in the target language spoken country, they can be able to speak the target language with a native like accent. So, if a learner starts his/her foreign language learning period abroad, in other words, in a place where the target language has been spoken, $s /$ he will get a better pronunciation because there are differences between the language learning environments, that is to say, to learn a foreign language in classrooms is different than to learn it abroad. The state some useful techniques to eliminate these negative factors over the pronunciation of EFL learners in our country and suggest some possible solutions.

\subsubsection{Instruction}

Foreign language instruction generally focuses on four main areas of development: listening, speaking reading and writing. Generally, foreign language curricula emphasize pronunciation in the first year of study as it introduces the target language's alphabets and sound system. However, pronunciation instruction rarely continues this focus in the higher level. Many researchers have explored the question of whether explicit instruction helps second language learners. Elliot (1995) found that, with 12 weeks of phonetic instruction, adult L2 learners of English can improve their allophonic articulation. Some pronunciation studies focus specifically on the pronunciation of supra-segmental sounds. 
Derwing and Munro (1997) conducted research in which ESL learners who had been studying for an average of ten years, participated in a speaking improvement course that focused on the supra-segmental features of pronunciation (e.g. stress, rhythm, intonation). Thirty-seven native listeners transcribed speech samples (true/false sentences) taken at the beginning of a 12-week course in order to assess the learners' intelligibility. Each sample was rated in order of comprehensibility and degree of accent. In the end, there was a significant improvement in the intelligibility, and better ratings over time of comprehensibility and accent. They showed that 30 language learners could alter their pronunciation in a reading task (Derwing and Rossiter, 2003). The previous research studies and reviewed literatures mentioned above confirm the roles of motivation, phonetic ability, prior English pronunciation study, the particular native language, and instruction concern for good pronunciation in studying a language as important factors affecting learners' pronunciation. Consequently, these causes and factors affecting the English pronunciation learning of students were employed in the questionnaire for collecting the data from students.

\subsection{Previous Research Study abroad}

The scholars of the field in the late 1960's and early 1970's stated that native-like pronunciation could not be totally taught, mainly because the cognitive code approach de-emphasized pronunciation in favor of grammar and vocabulary. Recently, the goal of pronunciation has changed from the attainment of 'perfect' pronunciation to the more realistic goals of developing functional, increased self-confidence, the development of speech monitoring abilities and speech to strategies for use beyond the classroom. Generally, there have been a couple of opposing viewpoints regarding teaching pronunciation. The first position holds that $\mathrm{L} 2$ learners are unable to achieve native-like ability, and the bulk of evidence within this strand of research comes from research on grammatical development as well as phonology (sound system and pronunciation). The Communicative approach holds that oral communication is the primary use of language; therefore, it should be central to the instruction (Goodwin, 2001). There has been a big shift within the field of language teaching with greater emphasis put on learners and learning rather than on teaching over the last years.

Along this new shift of interest, a move from specific linguistic competencies to broader communicative competencies has emerged as goals for teachers and students (Morley 1991: 481-520). The need for the integration of pronunciation with oral communication, a change of emphasis from to more emphasis on individual learner needs, meaningful task based practices, development of new teacher strategies for the teaching and introducing peer correction and group interaction were emphasized within the field of pronunciation teaching. It has been increasingly suggested that brain organization is modulated by practice, for example, through musical or linguistic training. Recent studies, using tests and brain measures, have revealed a connection between musical aptitude and second language linguistic abilities. Moreover, music practice may also have a modulatory effect on the brain's linguistic organization. Chen (2005) recommend that language teachers spend more time working on individual sounds by teaching English rhythms because they may find a surprising progress in students' English pronunciation.

Gamboa (2011) posits that the first language which is acquired during the first year of life is linked to personality, and students commonly feel uneasy to speak with a different rhythm and melody belonging to a different language. He suggests a teacher can help overcome this barrier and other challenges by thinking of the goal of pronunciation instruction not as helping students to sound like native speakers but as helping them to learn the core elements of spoken English so that they can be easily understood by others. In this regard Gamboa (2011) posits that the prosody of one's first language which is acquired during the first year of life is linked to personality, and students commonly feel uneasy to speak with a different rhythm and melody belonging to a different language. He suggests a teacher can help overcome this barrier and other challenges by thinking of the goal of pronunciation instruction not as helping students to sound like native speakers but as helping them to learn the core elements of spoken English pronunciation.

\subsection{Previous Research Study in Thailand, EFL classroom}

Experience in studying language is also regarded one of the factors that it is claimed may affect the choices of learning English pronunciation. However, a small number of studies have been carried out investigating the relationship between the experiences of English pronunciation. Purdie and Oliver (1999) reported the language learning strategies used by bilingual school-aged children coming from three main cultural groups. The results showed students who had been in Australia for a longer period of time ( 3 or less years and 4 or more) obtained significantly higher mean score for Cognitive strategies and for memory strategies. These findings, thus, can serve as the insight that experience in studying a language can affect the learning English pronunciation.

Purdie and Olive's study highlights the importance of experience in studying a language as one of the factors affecting the choices of language learning pronunciation. Their study also confirmed the findings of upper, Teacher, and Carlson's (1990) 
comprehensive study investigating studying abroad programs in Europe and the United States. As a result of their study, studying abroad is deemed to have an influence on students' thought and learning style, especially in their actual ability in language learning. Several areas of impact on participant's e.g. academic effects, effects on foreign language proficiency, cultural impact, change in attitudes and views are also indicated as factors contributing language learning strategy choices. These findings are congruent with Otlowski's (1998) conclusion, exerting that there are other factors including culture and nationality that can influence on learning pronunciations' choice. However, in the light of the influence of studying or staying abroad on language learning the English pronunciation, these studies confirm the roles of experiences in studying a language as an important factor affecting the choices of learning English pronunciation.

\section{Participants}

The participants that the researchers choose for collected data were students in 2nd and 3rd years of English for International Communication (EIC) Program, Business Administration and Liberal Arts Faculty at Rajamangala University of Technology Lanna (RMUTL) Tak. The total of participants is 51 . There are 10 males and 41 females who are studying in the first semester, academics year 2019. The researchers choose these participants because they had already learned the basic pronunciation of English. In each year, students had already learnt in pronunciation course. So, the researchers want to measure the self-assessment of participants by using a questionnaire.

\subsection{Research Instruments}

The research instrument was questionnaire developed based on observation. It's used to gather quantitative research information about the factors causing of 2nd and 3rd year students in English mispronunciation and analysis the data obtained from the Likert Rating Scale.

\section{Data analysis}

The quantitative data from the questionnaire were analyzed through the statistical software to calculate the means and standard deviation. The results were presented in by means of tables and explanations. The criteria for evaluating the quantitative data from the questionnaire were adapted from Likert Rating Scale. The data from a five-point rating scale was calculated for the arithmetic means and standard deviation. The means showed the students' factors or problems in English pronunciations. The criterion of means was from a range divided by the number of levels created. The following criteria were used to interpret the data as table 1.

Table 1: The interpretation of the self-assessment of participants on factors in English mispronunciation

\begin{tabular}{|l|l|}
\hline Mean Score & Interpretation \\
\hline $4.50-5.00$ & Usually True \\
\hline $3.50-4.49$ & Often True \\
\hline $2.50-3.49$ & Occasionally True \\
\hline $1.50-2.49$ & Rarely True \\
\hline $1.00-1.49$ & Usually Not True \\
\hline
\end{tabular}

\section{Results}

The researchers examined the questionnaire about content validity, which the main measurement methods for examining objectives. In this study, we used the Item Objective Congruence Index (IOC) to measure the validity of the research instrument. The result was within the specified standards (0.6-1.0).

The result was $100 \%$ for the response of the questionnaire from the 2 nd and 3re year students in English for International Communication (EIC) program at Rajamangala University of Technology Lanna Tak. Totally 51 participants, divided into 10 males and 41 females.

3.1 To find out the levels of the factors causing in English mispronunciation of 2 nd and 3rd year students in EIC program at RMUTL Tak 
From the questionnaire, the researchers have chosen four factors that were the cause of English mispronunciation, from observation and direct experience. The results were show in table 2-5.

Table 2: First Language Interference Factor

\begin{tabular}{|c|c|c|c|c|c|c|c|c|}
\hline \multirow{2}{*}{$\begin{array}{l}\text { First Language } \\
\text { Interference } \\
\text { or Native Language } \\
\text { Factor }\end{array}$} & \multicolumn{5}{|c|}{ Participants (percentage) } & \multirow[b]{2}{*}{$\overline{\mathbf{x}}$} & \multirow[b]{2}{*}{ S.D } & \multirow[b]{2}{*}{ Result } \\
\hline & $\begin{array}{l}\text { Usually } \\
\text { True } \\
\text { (5) }\end{array}$ & $\begin{array}{l}\text { Often } \\
\text { True } \\
\text { (4) }\end{array}$ & $\begin{array}{l}\text { Occasionally } \\
\text { True } \\
\text { (3) }\end{array}$ & $\begin{array}{l}\text { Rarely } \\
\text { True } \\
\text { (2) }\end{array}$ & $\begin{array}{l}\text { Usually } \\
\text { Not True } \\
\text { (1) }\end{array}$ & & & \\
\hline $\begin{array}{l}1.1 \text { I get used to } \\
\text { pronouncing English by } \\
\text { using a Thai accent. }\end{array}$ & $\begin{array}{l}13 \\
(25.5)\end{array}$ & $\begin{array}{l}24 \\
(47.1)\end{array}$ & $\begin{array}{l}12 \\
(23.5)\end{array}$ & $\begin{array}{l}2 \\
(3.9)\end{array}$ & - & 3.94 & 0.810 & $\begin{array}{l}\text { Often } \\
\text { True }\end{array}$ \\
\hline $\begin{array}{l}1.2 \text { I trust that It's not } \\
\text { necessary to always } \\
\text { pronounce English with } \\
\text { the correct } \\
\text { pronunciation } \\
\text { principles. }\end{array}$ & $\begin{array}{l}3 \\
(5.9)\end{array}$ & $\begin{array}{l}21 \\
(41.2)\end{array}$ & $\begin{array}{l}14 \\
(27.5)\end{array}$ & $\begin{array}{l}8 \\
(15.7)\end{array}$ & $\begin{array}{l}5 \\
(9.8)\end{array}$ & 3.18 & 1.090 & $\begin{array}{l}\text { Occasion } \\
\text { ally True }\end{array}$ \\
\hline \multicolumn{6}{|l|}{ Total } & 3.56 & 0.95 & $\begin{array}{l}\text { Often } \\
\text { True }\end{array}$ \\
\hline
\end{tabular}

From Table 2, found that the highest mean value factor was first language interference factor $(x=3.56, S D=0.95)$ and the result was at level 4 (Often True), divided into two sub-questions. In descending order, "I get used to pronouncing English by using a Thai accent." $(x=3.94, S D=0.810)$ and "I trust that It's not necessary to always pronounce English with the correct pronunciation principles." $(x=3.18, S D=0.90)$, respectively.

\section{Table 3: Phonetic Ability Factor}

\begin{tabular}{|c|c|c|c|c|c|c|c|c|}
\hline \multirow[b]{2}{*}{$\begin{array}{l}\text { Phonetic Ability } \\
\text { Factor }\end{array}$} & \multicolumn{5}{|c|}{ Participant (percentage) } & \multirow[b]{2}{*}{$\overline{\mathbf{x}}$} & \multirow[b]{2}{*}{ S.D } & \multirow[b]{2}{*}{ Result } \\
\hline & $\begin{array}{l}\text { Usually } \\
\text { True } \\
\text { (5) }\end{array}$ & $\begin{array}{l}\text { Often } \\
\text { True } \\
\text { (4) }\end{array}$ & $\begin{array}{l}\text { Occasionally } \\
\text { True } \\
\text { (3) }\end{array}$ & $\begin{array}{l}\text { Rarely } \\
\text { True } \\
\text { (2) }\end{array}$ & $\begin{array}{l}\text { Usually } \\
\text { Not True } \\
(1)\end{array}$ & & & \\
\hline $\begin{array}{l}2.1 \text { I don't know } \\
\text { how to pronounce } \\
\text { English. (Manner of } \\
\text { Articulation) }\end{array}$ & $\begin{array}{l}3 \\
(5.9)\end{array}$ & $\begin{array}{l}21 \\
(41.2)\end{array}$ & $\begin{array}{l}15 \\
(29.4)\end{array}$ & $\begin{array}{l}6 \\
(11.18)\end{array}$ & $\begin{array}{l}6 \\
(11.18)\end{array}$ & 3.18 & 1.108 & $\begin{array}{l}\text { Occasionally } \\
\text { True }\end{array}$ \\
\hline $\begin{array}{l}\text { 2.2 I don't know the } \\
\text { place of } \\
\text { Articulation. }\end{array}$ & $\begin{array}{l}5 \\
(9.8)\end{array}$ & $\begin{array}{l}15 \\
(29.4)\end{array}$ & $\begin{array}{l}25 \\
(49.0)\end{array}$ & $\begin{array}{l}3 \\
(5.9)\end{array}$ & $\begin{array}{l}3 \\
(5.9)\end{array}$ & 3.31 & 0.948 & $\begin{array}{l}\text { Occasionally } \\
\text { True }\end{array}$ \\
\hline $\begin{array}{l}2.3 \text { I unable to } \\
\text { pronounce some } \\
\text { words in English } \\
\text { that it doesn't have } \\
\text { in Thai, such as / th } \\
/, / \mathrm{V} /, / \mathrm{g} / \text { and / } \\
\text { z/ etc. }\end{array}$ & $\begin{array}{l}10 \\
(19.6)\end{array}$ & $\begin{array}{l}13 \\
(25.5)\end{array}$ & $\begin{array}{l}13 \\
(25.5)\end{array}$ & $\begin{array}{l}12 \\
(23.5)\end{array}$ & $\begin{array}{l}3 \\
(5.9)\end{array}$ & 3.29 & 1.205 & $\begin{array}{l}\text { Occasionally } \\
\text { True }\end{array}$ \\
\hline $\begin{array}{l}2.4 \text { I don't know the } \\
\text { patterns of the } \\
\text { highs and lows in } \\
\text { English sentences. } \\
\text { (Intonation) }\end{array}$ & $\begin{array}{l}7 \\
(13.7)\end{array}$ & $\begin{array}{l}14 \\
(27.5)\end{array}$ & $\begin{array}{l}18 \\
(35.3)\end{array}$ & $\begin{array}{l}10 \\
(19.6)\end{array}$ & $\begin{array}{l}2 \\
(3.9)\end{array}$ & 3.27 & 1.060 & $\begin{array}{l}\text { Occasionally } \\
\text { True }\end{array}$ \\
\hline
\end{tabular}




\begin{tabular}{|l|l|l|l|l|l|l|l|l|}
\hline $\begin{array}{l}2.5 \text { I don't know the } \\
\text { correct way to } \\
\text { pronounce English } \\
\text { (Stress) }\end{array}$ & $\begin{array}{l}19 \\
(17.6)\end{array}$ & $\begin{array}{l}16 \\
(37.3)\end{array}$ & $\begin{array}{l}7 \\
(31.4)\end{array}$ & $(13.7)$ & - & 3.59 & 0.942 & Often True \\
\hline $\begin{array}{l}2.6 \quad \text { can't } \\
\text { distinguish the } \\
\begin{array}{l}\text { American and } \\
\text { British accents. }\end{array}\end{array}$ & $\begin{array}{l}14 \\
(27.5)\end{array}$ & $\begin{array}{l}12 \\
(23.5)\end{array}$ & $\begin{array}{l}14 \\
(27.5)\end{array}$ & $\begin{array}{l}9 \\
(17.6)\end{array}$ & $\begin{array}{l}2 \\
(3.9)\end{array}$ & 3.53 & 1.189 & Often True \\
\hline \multicolumn{2}{|l|}{} & & 3.36 & 1.075 & Often True \\
\hline
\end{tabular}

From Table 3, Phonetic ability factors was the second mean value $(x=3.36$, S.D. $=1.075)$ and the result was at level 4 (Often True), divided into six sub-questions. In descending order, found that "I don't know the correct ways to pronounce English" ( $x$ $=3.59$, S.D. $=0.942$ ), "I can't distinguish the American and British accents." ( $x=3.53, \mathrm{SD}=1.189)$, "I don't know the place of articulation." ( $x=3.31, \mathrm{SD}=0.948)$, "3 I unable to pronounce some words in English that it doesn't have in Thai, such as / th / , / v / , / g / and / z / etc." ( $\mathrm{x}=3.29, \mathrm{SD}=1.205)$, "I don't know the patterns of the highs and lows in English sentences." $(\mathrm{x}=$ 3.27 , S.D. $=1.060)$ and "I don't know how to pronounce English." ( $x=3.18$, S.D. = 1.108), respectively.

Table 4: Experience in Studying English Factor

\begin{tabular}{|c|c|c|c|c|c|c|c|c|}
\hline \multirow{2}{*}{$\begin{array}{l}\text { Experience in } \\
\text { studying } \\
\text { English } \\
\text { Factor }\end{array}$} & \multicolumn{5}{|c|}{ Participant (percentage) } & \multirow[b]{2}{*}{$\overline{\mathbf{x}}$} & \multirow[b]{2}{*}{ S.D } & \multirow[b]{2}{*}{ Result } \\
\hline & $\begin{array}{l}\text { Usually } \\
\text { True } \\
\text { (5) }\end{array}$ & $\begin{array}{l}\text { Often } \\
\text { True } \\
\text { (4) }\end{array}$ & $\begin{array}{l}\text { Occasionally } \\
\text { True } \\
\text { (3) }\end{array}$ & $\begin{array}{l}\text { Rarely } \\
\text { True } \\
\text { (2) }\end{array}$ & $\begin{array}{l}\text { Usually } \\
\text { Not True } \\
\text { (1) }\end{array}$ & & & \\
\hline $\begin{array}{l}4.1 \text { I focused } \\
\text { more on } \\
\text { grammar than } \\
\text { to practice } \\
\text { speaking aloud } \\
\text { for use in } \\
\text { conversation. }\end{array}$ & $\begin{array}{l}7 \\
(13.7)\end{array}$ & $\begin{array}{l}10 \\
(19.6)\end{array}$ & $\begin{array}{l}22 \\
(43.1)\end{array}$ & $\begin{array}{l}11 \\
(21.6)\end{array}$ & $\begin{array}{l}1 \\
(2.0)\end{array}$ & 3.22 & 1.006 & $\begin{array}{l}\text { Occasionally } \\
\text { True }\end{array}$ \\
\hline $\begin{array}{l}4.2 \text { I didn't have } \\
\text { the opportunity } \\
\text { to practice } \\
\text { English } \\
\text { pronunciation } \\
\text { with foreigners. }\end{array}$ & $\begin{array}{l}2 \\
(3.9)\end{array}$ & $\begin{array}{l}17 \\
(33.3)\end{array}$ & $\begin{array}{l}17 \\
(33.3)\end{array}$ & $\begin{array}{l}12 \\
(23.5)\end{array}$ & $\begin{array}{l}3 \\
(5.9)\end{array}$ & 3.06 & 0.988 & $\begin{array}{l}\text { Occasionally } \\
\text { True }\end{array}$ \\
\hline $\begin{array}{l}4.3 \text { I didn't have } \\
\text { the opportunity } \\
\text { to practice } \\
\text { English } \\
\text { pronunciation } \\
\text { in class. }\end{array}$ & $\begin{array}{l}2 \\
(3.9)\end{array}$ & $\begin{array}{l}10 \\
(19.6)\end{array}$ & $\begin{array}{l}25 \\
(49.0)\end{array}$ & $\begin{array}{l}12 \\
(23.5)\end{array}$ & $\begin{array}{l}2 \\
(3.9)\end{array}$ & 2.96 & 0.871 & $\begin{array}{l}\text { Occasionally } \\
\text { True }\end{array}$ \\
\hline $\begin{array}{l}\text { 4.4 I didn't have } \\
\text { the opportunity } \\
\text { to practice } \\
\text { English } \\
\text { conversation in } \\
\text { class. }\end{array}$ & - & $\begin{array}{l}11 \\
(21.6)\end{array}$ & $\begin{array}{l}22 \\
(43.1)\end{array}$ & $\begin{array}{l}16 \\
(31.4)\end{array}$ & $\begin{array}{l}2 \\
(3.9)\end{array}$ & 2.82 & 0.817 & $\begin{array}{l}\text { Occasionally } \\
\text { True }\end{array}$ \\
\hline
\end{tabular}




\begin{tabular}{|c|c|c|c|c|c|c|c|c|}
\hline $\begin{array}{l}4.5 \text { I tend to } \\
\text { ignore criticism } \\
\text { or suggestions } \\
\text { from } \\
\text { experienced } \\
\text { people who } \\
\text { recommend } \\
\text { English } \\
\text { pronunciation. }\end{array}$ & $\begin{array}{l}5 \\
(9.8)\end{array}$ & $\begin{array}{l}6 \\
(11.8)\end{array}$ & $\begin{array}{l}20 \\
(39.2)\end{array}$ & $\begin{array}{l}17 \\
(33.3)\end{array}$ & $\begin{array}{l}3 \\
(5.9)\end{array}$ & 2.86 & 1.040 & $\begin{array}{l}\text { Occasionally } \\
\text { True }\end{array}$ \\
\hline Total & & & & & & 2.98 & 0.944 & $\begin{array}{l}\text { Occasionally } \\
\text { True }\end{array}$ \\
\hline
\end{tabular}

From Table 4, Experience in Studying English Factor was the third mean value $(x=2.98$, S.D. $=0.944)$ and the result was at level 3 (Occasionally True), divided into five sub-questions. In descending order, found that "I focused more on grammar than to practice speaking aloud for use in conversation." ( $x=3.22$, S.D. $=1.006)$, "I didn't have the opportunity to practice English pronunciation with foreigners." ( $x=3.06$, SD $=0.988)$, "I didn't have the opportunity to practice English pronunciation in class." ( $x=2.96, \mathrm{SD}=0.871)$, "I tend to ignore criticism or suggestions from experienced people who recommend English pronunciation." ( $x=2.86, \mathrm{SD}=1.040)$ and "I didn't have the opportunity to practice English conversation in class." $(x=2.82$, $\mathrm{SD}=0.817)$, respectively.

Table 5: Motivation Factor

\begin{tabular}{|c|c|c|c|c|c|c|c|c|}
\hline \multirow{2}{*}{$\begin{array}{l}\text { Motivation } \\
\text { Factor }\end{array}$} & \multicolumn{5}{|c|}{ Participant (percentage) } & \multirow[b]{2}{*}{$\overline{\mathbf{x}}$} & \multirow[b]{2}{*}{ S.D } & \multirow[b]{2}{*}{ Result } \\
\hline & $\begin{array}{l}\text { Usually } \\
\text { True } \\
\text { (5) }\end{array}$ & $\begin{array}{l}\text { Often } \\
\text { True } \\
(4) \\
\end{array}$ & $\begin{array}{l}\text { Occasionally } \\
\text { True } \\
\text { (3) }\end{array}$ & $\begin{array}{l}\text { Rarely } \\
\text { True } \\
\text { (2) }\end{array}$ & \begin{tabular}{|l} 
Usually \\
Not True \\
(1) \\
\end{tabular} & & & \\
\hline $\begin{array}{l}3.1 \text { I don't like } \\
\text { listening to } \\
\text { English music. }\end{array}$ & $\begin{array}{l}2 \\
(3.9)\end{array}$ & $\begin{array}{l}2 \\
(3.9)\end{array}$ & $\begin{array}{l}19 \\
(37.3)\end{array}$ & $\begin{array}{l}16 \\
(31.4)\end{array}$ & $\begin{array}{l}12 \\
(23.5)\end{array}$ & 2.33 & 1.013 & Rarely True \\
\hline $\begin{array}{l}3.2 \text { I don't like } \\
\text { watching } \\
\text { English } \\
\text { programs or } \\
\text { movies. }\end{array}$ & $\begin{array}{l}2 \\
(3.9)\end{array}$ & $\begin{array}{l}5 \\
(9.8)\end{array}$ & $\begin{array}{l}15 \\
(29.4)\end{array}$ & $\begin{array}{l}22 \\
(43.1)\end{array}$ & $\begin{array}{l}7 \\
(13.7)\end{array}$ & 2.47 & 0.987 & Rarely True \\
\hline $\begin{array}{l}3.3 \text { I don't } \\
\text { like to hear } \\
\text { foreign news. }\end{array}$ & $\begin{array}{l}1 \\
(2.0)\end{array}$ & $\begin{array}{l}10 \\
(19.6)\end{array}$ & $\begin{array}{l}16 \\
(31.4)\end{array}$ & $\begin{array}{l}20 \\
(39.2)\end{array}$ & $\begin{array}{l}4 \\
(7.8)\end{array}$ & 2.69 & 0.948 & $\begin{array}{l}\text { Occasionally } \\
\text { True }\end{array}$ \\
\hline $\begin{array}{l}3.4 \quad \text { I don't } \\
\text { like } \\
\text { playing } \\
\text { games with } \\
\text { English } \\
\text { language. }\end{array}$ & $\begin{array}{l}1 \\
(2.0)\end{array}$ & $\begin{array}{l}7 \\
(13.7)\end{array}$ & $\begin{array}{l}18 \\
(35.3)\end{array}$ & $\begin{array}{l}14 \\
(27.5)\end{array}$ & $\begin{array}{l}11 \\
(21.6)\end{array}$ & 2.47 & 1.047 & Rarely True \\
\hline $\begin{array}{l}3.5 \text { I think } \\
\text { speaking } \\
\text { English is } \\
\text { difficult, so } \\
\text { I'm avoiding } \\
\text { to learning or } \\
\text { practicing }\end{array}$ & - & $\begin{array}{l}9 \\
(17.6)\end{array}$ & $\begin{array}{l}18 \\
(35.3)\end{array}$ & $\begin{array}{l}15 \\
(29.4)\end{array}$ & $\begin{array}{l}9 \\
(17.6)\end{array}$ & 2.53 & 0.987 & $\begin{array}{l}\text { Occasionally } \\
\text { True }\end{array}$ \\
\hline
\end{tabular}


From Table 5, Motivation Factor was the lowest mean value $(x=2.50$, S.D. $=0.996)$ and the result was at level 3 (Occasionally True), divided into five sub-questions. In descending order, found that "I don't like to hear foreign news." ( $x=2.69$, S.D. = 0.948), "I think speaking English is difficult, so I'm avoiding to learning or practicing." ( $x=2.53, \mathrm{SD}=0.987)$, "I don't like to playing games with English language." $(x=2.47, S D=1.047)$, "I don't like watching English programs or movies." $(x=2.47$, SD $=0.987$ ) and "I don't like listening to English music." ( $x=2.33, \mathrm{SD}=1.013)$, respectively.

3.2 To find out the most and least in the factors causing in English mispronunciation of 2 nd and 3rd year students in EIC program at RMUTL Tak

Figure 1 First Language Interference Factor

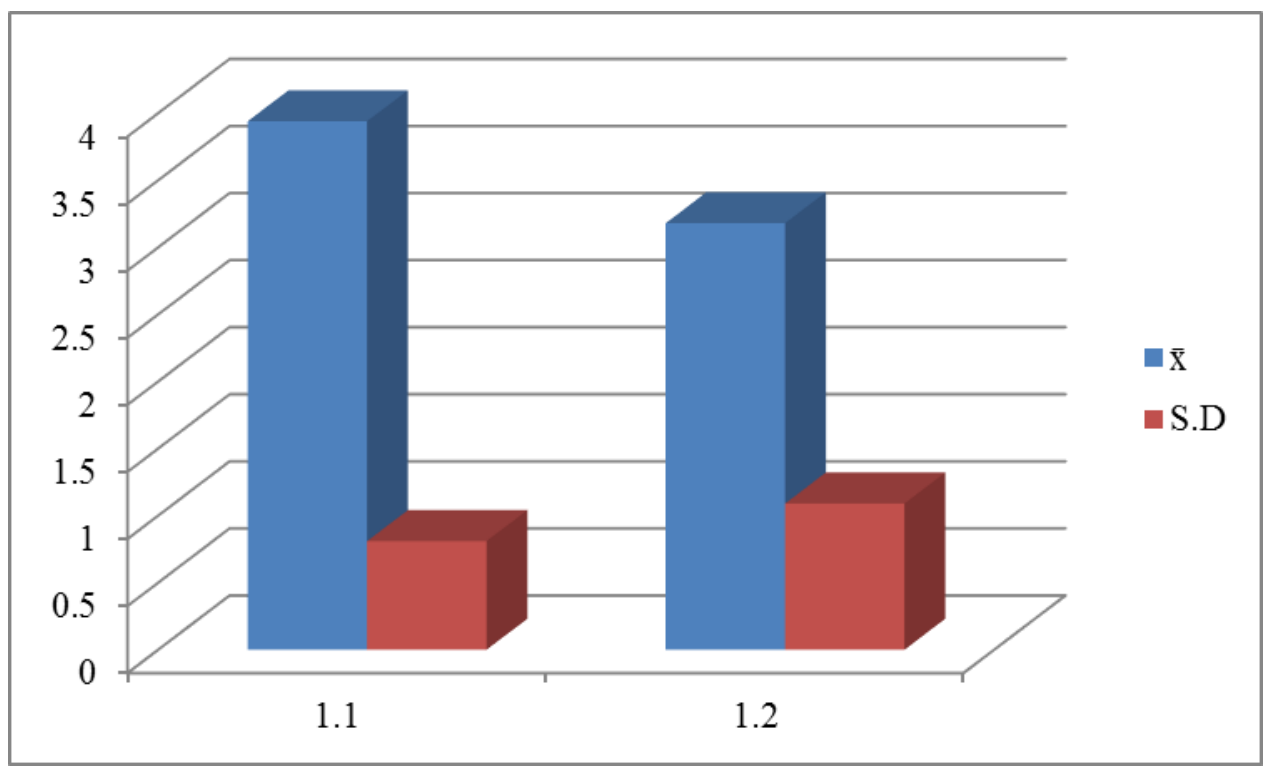

The highest mean value of the factors causing in English mispronunciation of 2 nd and 3rd year EIC students at RMUTL Tak, from respondents found that first language interference factor has the most result, from the two sub-questions in the questionnaire "I get used to pronouncing English by using a Thai accent." ( $\bar{x}=3.94$, S.D. $=0.810)$ and "I trust that it's not necessary to always pronounce English with the correct pronunciation principles." ( $\bar{x}=3.18, S . D .=1.090)$, respectively.

\section{Figure 2 Motivation Factor}

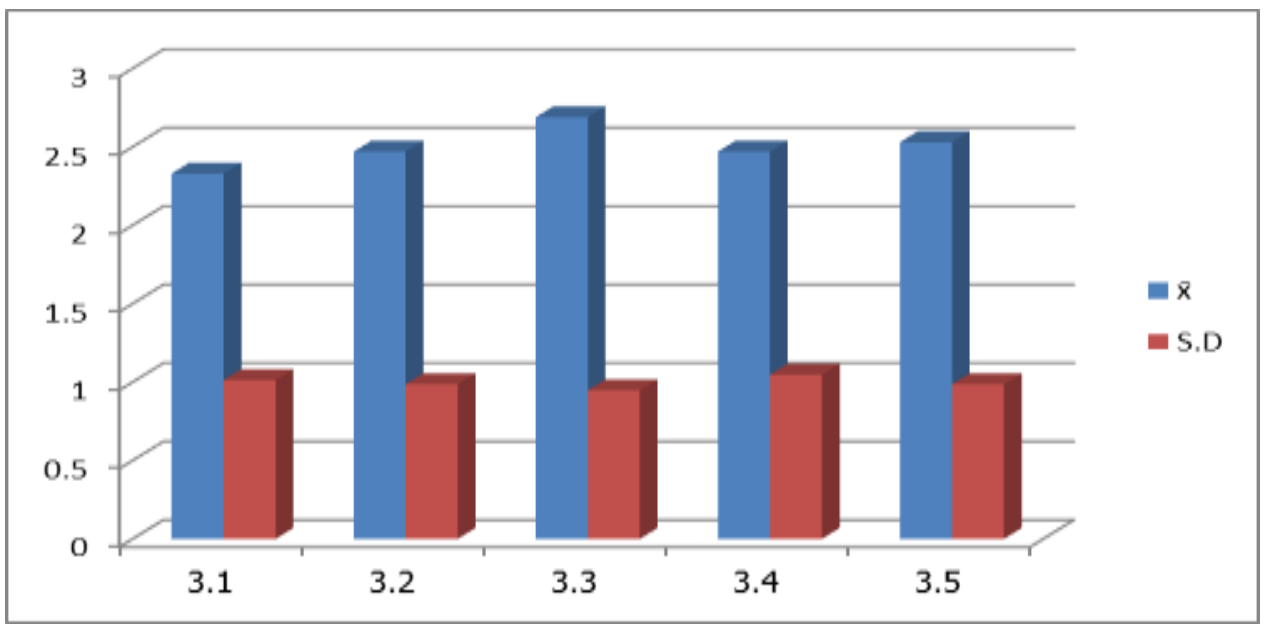


For the lowest factor was motivation factor, from the five sub-questions in the questionnaire which were arranged in descending order "I don't like to hear foreign news." ( $\bar{x}=2.69$, S.D. $=0.948)$, "I think speaking English is difficult, so I'm avoiding learning or practicing." ( $\bar{x}=2.53$, S.D. $=0.987)$, "I don't like watching English programs or movies." and "I don't like to playing games with English language." both of sub-questions have the same mean value $(\bar{x}=2.53$, S.D. = 1.047), and lastly "I don't like listening to English music." ( $\bar{x}=2.33$, S.D. $=1.013)$, respectively.

\section{Discussion}

The result of this study indicated that all 2nd and 3rd year students in English for International Communication (EIC) Program evaluated the factor causing in English mispronunciation found that first language interference factor have the highest mean value $(\bar{x}=3.56$, S.D. $=0.95)$, The second was phonetic ability factor $(\bar{x}=3.36$, S.D. $=1.075)$, third was experience in studying English factor $(\bar{x}=2.98, S . D .=0.944)$ and the lastly was motivation factor have the lowest mean value $(\bar{x}=2.50$, S.D. $=0.996)$.

In the last part of the questionnaire, the researchers asked the respondents to express additional opinions about the English mispronunciation and summarized as follows:

1. English is very necessary in everyday life.

2. Participants would like to have the opportunity to practice learning more English languages, not just subjects that must be studied in the classroom.

3. Talking with native speakers will give you the opportunity to improve your English speaking skills quickly.

4. Participants would like the classroom to have more practice in conversation and pronunciation in English than before.

Additionally, the results of the research, found that the factors causing mispronunciation were the first language interference factor. According to Avery \& Ehrlich (1987), indicated that the sound system of the native language can influence the English pronunciation of students in different ways, which makes the students not interested to pronounce due to difficulty.

Therefore, mispronunciation was including with the theories. According to Harmer (2001), many teachers didn't pay attention to English pronunciation and many students said that they don't need to learn pronunciation because communication was more important than pronunciation.

The least factors causing in English mispronunciation was motivation, the motivation of each student was different and also students cannot be measured the motivation. The participants are chosen by the researcher studying in English for international communication. So, they will have good motivation for studying and pronunciation in English. Therefore this factor has the least result. According to Brown (1994: 114-115) the motivation is thought of as an inner drive, impulse, emotion, or desire that moves one to a particular action. He also stated that learning a foreign language requires some of all three levels of motivation which can be global, situational, or task-oriented. For example, a learner may possess high global motivation but low task motivation in the written mode of the language. In addition, should be an investigation about a variety of participants such as students from a different program and or use other research instruments such as interview and pronunciation test to measure the results to be more effective.

\section{Conclusion}

The objectives of this study were to investigate the factor causing in English mispronunciation of 2nd and 3rd year students in English for International Communication Program at Rajamangala University of Technology Lanna Tak to find the answers for two research questions:

1. What are the levels of factors causing in English mispronunciation of 2 nd and 3rd year students in EIC at RMUTL Tak?

2. What are the most and least in factors causing of English mispronunciation of 2 nd and 3rd year students in EIC at RMUTL Tak?

This research investigated the $2^{\text {nd }}$ and $3^{\text {rd }}$ year students in English for International communication (EIC) program, the results in general revealed that the factor causing in English mispronunciation is that first language interference factor which has the highest mean value. Clearly seen that the second factor was phonetic ability, the third was experience in studying English factor and the lastly was motivation factor has the lowest mean value respectively.

Therefore, it can be said that the least factors causing in English mispronunciation was motivation, the motivation of each student was different and also students cannot be measured the motivation. The participants are chosen by the researcher 
studying in English for international communication. Therefore, they will have good motivation for studying and pronunciation in English and this factor has the least result.

\subsection{Limitation and suggestion for future research}

The results of this research should be interpreted carefully for several reasons. First, it should be the limitation of a number of students, the results should call for subsequent studies analyzing a bigger group of students. Second, as discussed in the literature, it will be possible that pronunciation factors of students might be influenced by others e.g., age, field of study, phonetic ability etc.

The researchers would like to recommend for future studies on English mispronunciation that there should explore with different students such as other programs because although they have less English courses than EIC students' program, also they may have different factors and concerns of English mispronunciation. Consequently, it will be data base for anyone who likes to know about English mispronunciation.

In addition, it should investigate various factors in term of internal and external factors affecting English mispronunciation such as concerns, perceptions and other impacts of English pronunciation factor or instruction factors, etc.

Moreover, further research should investigate relationship between the student's English language pronunciation competence and real performance.

\section{References}

[1] Avery, P. \& Ehrlich, S. (1987). Preliminary considerations in the teaching of pronunciation. TESL Center.

[2] Butler-Pascoe, M. E., \& Wiburg, K. M. (2003). Technology and Teaching English Language Learners. Pearson Education, Inc.

[3] Brown, A. (1992). Approaches to Pronunciation Teaching. Macmillan.

[4] Brown, H. (1994). Teaching by principles: An interactive approach to language pedagogy. Englewood Cliffs.

[5] Celce-Murcia, M., \& Goodwin, J. M. (1991). Teaching Pronunciation. In M. Celce-Murcia (Ed.) Teaching English as a Second or Foreign Language (pp.136-153). Newbury House.

[6] Chen, SF., (2005). Cooperative learning, multiple intelligences and proficiency: Application in college English language teaching and learning. Australian Catholic University.

[7] Derwing, T. \& Munro, M. (2005). Language Accent and Pronunciation Teaching A Research-based Approach, TESOL Quarterly, 39 (3), 379-396.

[8] Derwing, T. M. and Munro, M. J. (1997). Accent, intelligibility and comprehensibility: evidence from four L1s. JSTOR Studies in Second Language Acquisition, 19, 1-16.

[9] Derwing, T. and Rossiter, M. (2003). The effects of pronunciation instruction on the accuracy, fluency, and complexity of L2 accented speech. Applied Language Learning, 13(1), 1-17.

[10] Elliot, A.R. (1995). Foreign language phonology: Field independence, attitude, and the success of formal instruction in Spanish pronunciation. The Modern Language Journal, 79 (iv), 530-542.

[11] Gamboa Silva, L. P. (2011). Strategies to improve English pronunciation in young learners B.S. Thesis. Pontificia Universidad Católica del Ecuador Sede Ambato.

[12] Gillette, G. (1994). On speaking terms: Practical guide to pronunciation for ABLE/ESL teachers. Euclid. Resource Center.

[13] Goodwin, J. (2001). Teaching pronunciation. In M. Celce-Murcia (Ed). Teaching English as a second or foreign language. Heinle and Heinle.

[14] Harmer, J. (2001). The Practice of English Language Teaching. Longman.

[15] Haymes, J. (2000). The development of interactive oral proficiency in the classroom. http: //www.developing teachers.com/articles tchtraining/orprof1_jake.htm

[16] James, R. B. (2010). Teaching Pronunciation Gets a Bad R.A.P: A Framework for Teaching Pronunciation. University of Foreign Studies.

[17] Kenworthy, J. (1987). Teaching English pronunciation. Longman.

[18] Kenworthy, J. (1987). Teaching English Pronunciation. Longman.

[19] Kanoksilapatham, B. (1992). An analysis of English pronunciation of third year English major students. M.A. Thesis: Silpakorn University.

[20] Marinova-Todd, S. H., Marshall, D. B., \& Snow, C. E. (2000). Three misconceptions about age and L2 learning. TESOL Quarterly, 34(1), 9-34.

[21] Moyer, A. (2007). Do language attitudes determine accent? A study of bilinguals in the USA. Journal of Multilingual and Multicultural Development, 28(6), 502-518.

[22] Morley, J. (1994). In J. Morley (Ed.), Pronunciation Theory and Pedagogy, A Multidimensional Curriculum Design for Speechpronunciation Instruction (pp.64-91). New Directions.

[23] Morley, J. (1991). The Pronunciation Component in Teaching English to Speakers of Other Languages, TESOL Quarterly, 25(3), 481520.

[24] Otlowski, M. (1998). Pronunciation: What Are the Expectations? The Internet TESL Journal, 5(1). http://www.iteslj.org./ Article / Otlowski poronunciation.html.

[25] Purdie, N., \& Oliver, R. (1999). Language strategies used by bilingual school-aged children. System, 27, 375-388. 
[26] Pourhosein Gilakjani, A. (2016). What Factors Influence the English Pronunciation of EFL Learners? Modern Journal of Language Teaching Methods, 6(2), 314-326.

[27] Scovel, T. (1988). A Time to Speak: A Psycholinguistic Inquiry into the Critical Period for Human Speech. Newbury House.

[28] Serttikul, S. (2005). The production of final /-I/ in English words in Thai and English contexts by Thai speakers with different Englishlanguage experience. Unpublished Master's thesis, Chulalongkorn University.

[29] Siriwisut. (1994). The variation of final /I/ in English words in Thai by Thai speakers with different English-language experience. Unpublished M.A. Thesis: Chulalongkorn University.

[30] Senel, M. (2006). Suggestions for beautifying the pronunciation of EFL learners in Turkey. Journal of Language and Linguistic Studies, 2(1), 111-125.

[31] Yates, L., \& Zielinski, B. (2009). Give It a Go: Teaching Pronunciation to Adults. Sydney, Australia. http://www.ameprc.mq.edu.au/resources/classroom_resources/give_it_a_go 